\title{
Poliomyelitis Distribution in the United States
}

\author{
By ROBERT E. SERfling, Ph.D., and IDA L. Sherman, M.S.
}

$\mathrm{I}^{\mathrm{N}}$ N THE EARLY summer of 1894 inhabitants of the Otter Creek Valley in western Vermont became aware of a strange paralytic disease in their community. It seemed to select younger children as particular victims although a few adults were also affected. This first notable epidemic of poliomyelitis in the United States was carefully investigated by Dr. C. S. Caverly, president, Vermont State Board of Health. His field studies, constituting a classic model of "shoe-leather" epidemiology, mark the beginning of our modern knowledge of poliomyelitis. In the following years other investigations conducted in the Caverly pattern demonstrated the extensive distribution of the disease and indicated the need for systematic morbidity reporting.

Massachusetts, in 1907, was the first State (1) to require notification of all cases of poliomyelitis. In 1910, the Surgeon General of the Public Health Service requested all States to submit reports on poliomyelitis for 1909 and 1910. This initiated national reporting of poliomyelitis, although regular inclusion of reports from all States was not achieved until about 1922 . Since that time a large body of data has accumulated, forming an increasingly comprehensive base for continuing analyses of elementary epidemiological characteristics, such as secular trends, geographic distribution, and seasonal variation. A number of excellent analyses have been published $(2,3,4,5)$, but

Dr. Serfling and Mrs. Sherman are chief and assistant chief, respectively, of the statistics section, epidemiology branch, Communicable Disease Center, Public Health Service, Atlanta, Ga. the most recent include only the years through 1946 in the United States $(6,7)$. Sabin (8) reviewed epidemiological characteristics of a number of poliomyelitis outbreaks throughout the world.

Certain epidemiological characteristics of poliomyelitis have changed with time. In the United States, annual rates both of reported cases and of deaths have shown an upward trend, particularly during the past decade. In earlier decades a lower incidence was observed in southern States than in northern States. This difference is less apparent in recent years.

Continuing studies and analysis of these elementary epidemiological characteristics and their changes are indicated for any infectious disease that remains as a serious problem in the country. Furthermore, discovery of the value of gamma globulin in the prophylaxis of poliomyelitis $(9,10)$ poses difficult problems as to the best way to utilize available supplies.

The fullest possible knowledge of the current epidemiological pattern of poliomyelitis as revealed by morbidity and mortality reports may be useful in guiding administrative decisions. For these reasons the present paper has been prepared. The past history of poliomyelitis as recorded in published literature and official reports was reviewed and special attention was given the period 1932 to 1952 with particular emphasis on changing patterns of the past 5 to 10 years.

\section{National Incidence}

The trend of the national case and death rates in the United States during the period 1910-52, is shown in figure 1 . Since both cases and 
deaths were not reported from the same group of States during earlier years, the rates in figure 1 were based on reports from those States which reported both cases and deaths. The record of national incidence of poliomyelitis in the United States falls naturally into four periods:

1. Prior to 1909, when information on incidence, except for a few States, depended on descriptive accounts in the epidemiological literature.

2. From 1909-16, when published reports were available from some States. These were supplemented by special studies of Lavinder, Freeman, and Frost, and their summaries give more complete information on the period.

3. From 1917 through the epidemic year 1931, during which time reporting gradually became more complete. By the middle 1920's most States were reporting annually.

4. From 1932 until the present, during which time national reporting of both cases and deaths has been essentially complete. Because of the obvious differences which characterize national reporting in the different periods, they are presented separately in this discussion.

\section{Early Years}

During the 1894 outbreak in Vermont, Caverly collected information on 132 cases. Of these, 119 had shown paralysis, 7 had died before paralysis was noted, and 6, although exhibiting symptoms characteristic of early stages of the illness, had not developed paralysis. In Rutland, the largest community in the affected area, 55 of the 12,000 inhabitants had been stricken-an attack rate of 460 cases per 100,000 population. In nearby Proctor, a town of 2,000 persons, 27 cases had occurred. The remaining 50 cases were scattered through a dozen small communities in the area.

Two years later, in a final report of his investigations (11), Caverly concluded that the disease was "epidemic poliomyelitis," possibly a variant form of the "infantile paralysis" which in the United States had been known principally as an endemic disease of relatively infrequent occurrence.

In the succeeding years similar outbreaks occurred with increasing frequency in many parts of the country. In 1908 two papers $(12,13)$ summarized accounts of 17 poliomyelitis epidemics in the United States and others throughout the world. By this time, outbreaks had been described in Alabama, California, Florida, Illinois, Maine, Massachusetts, Michigan, Missouri, New York, Pennsylvania, and Wisconsin. These seem generally to have been of smaller scale than the Rutland episode.

In New York City, however, the 1907 outbreak was the largest then recorded in any place. The impact led to an extensive retrospective investigation initiated in October of 1907. The study (14) was conducted by mail and produced detailed information on 752 cases. It was estimated that in all, about 2,500 cases had occurred. Although cases were somewhat concentrated on the east side of Manhattan, the epidemic had extended northward to Poughkeepsie and throughout the western end of Long Island. The case fatality was estimated to be 5-7 percent, about half that of the Rutland outbreak.

In Massachusetts, where smaller outbreaks had been noticed since 1893, incidence was also high in 1907 and the State made poliomyelitis a reportable disease. In 1908, 136 cases were reported in Massachusetts (1). In midwestern Minnesota, 150 cases were recorded, and in Wisconsin, 408. In the following year, 1909, a great outbreak struck in Nebraska. Description of this epidemic (15) was also based on a retrospective study. In answers to letters, 58 physicians reported 999 cases in 18 counties. The greatest number of cases, 384, was reported from Polk County, with a population of 10,000. Douglas County (1910 population, 168,546) reported 79 cases, a rate slightly less than 50 per 100,000 population, and comparable to that of the New York City epidemic of 1907. In 1910 Massachusetts reported 845 cases, Pennsylvania 1,112 , and in the midwest, Minnesota and Iowa each recorded more than 600 cases. In the far west, nearly 400 cases occurred in the State of Washington. On August 9 of that year (1910) the Surgeon General of the Public Health Service initiated the request that started national reporting of poliomyelitis. In the same year provision was also made for separate classification of poliomyelitis deaths in the national vital statistics summary. 
Figure 1. Annual poliomyelitis case and death rates in States reporting both cases and deaths, United Stafes, 1910-52.
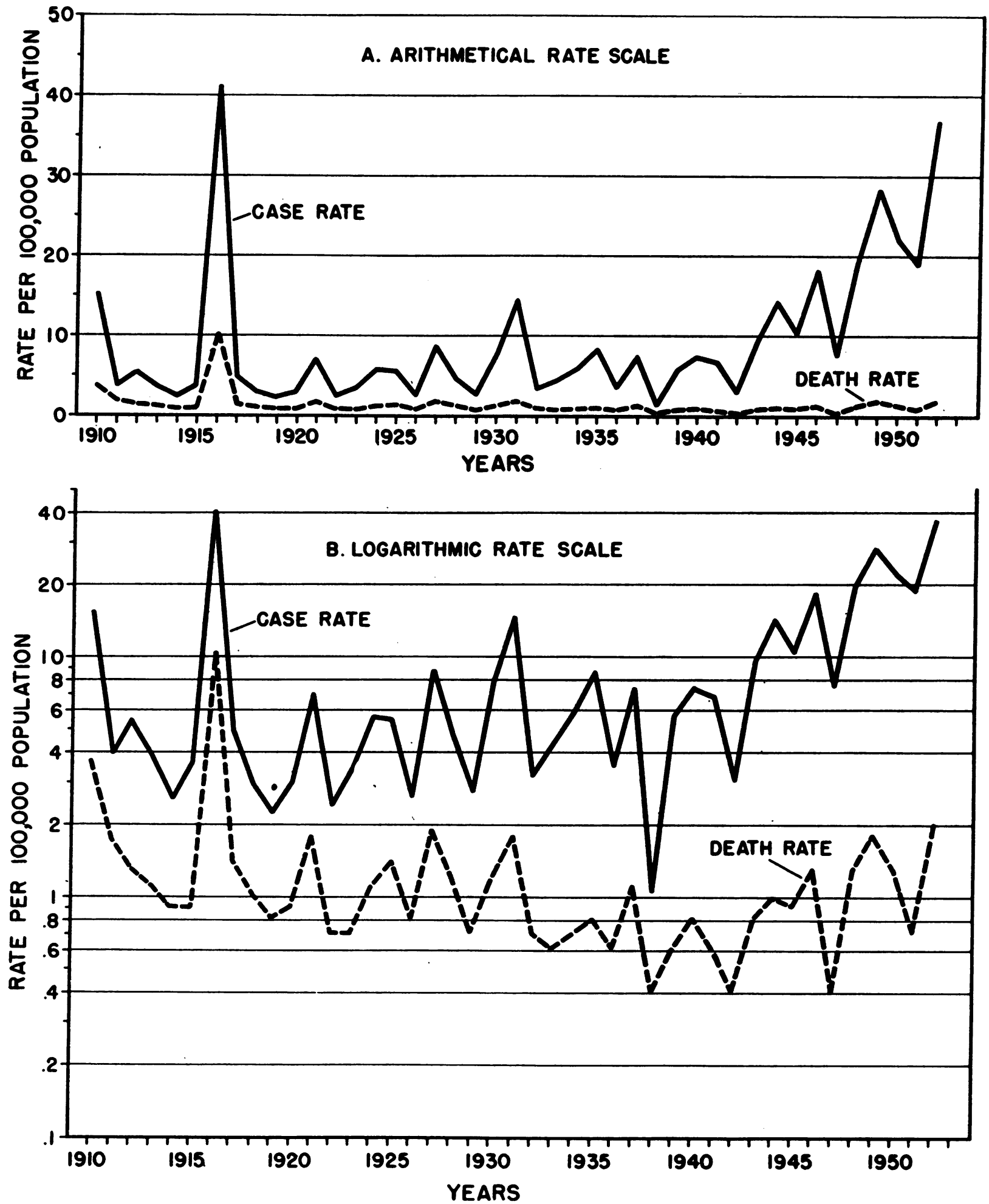

Sources: Cases, 1910-50_-Public Health Service: The Notifiable Diseases (Pub. Health Rep. Supp.). 1951-National Office of Vital Statistics: Reported Incidence of Notifiable Diseases in the United States, 1951, Annual Supplement to Weekly Morbidity Report, vol. 2, No. 53, 1953. 1952-National Office of Vital Statistics: Morbidity and Mortality Weekly Report, vol. 1, Nos. 1-53 inclusive. Deaths, 1910-49, Vital Statistics of the United States. U. S. Bureau of the Census, 1910-44; U. S. Public Health Service 1945-49. 1950-51 data from advance releases, 1952 data from 10 percent mortality sample, Jan.-Nov., National Office of Vital Statistics.

Vol. 68, No. 5, May 1953 


\section{Years 1909-16}

For 1909 only 3 States submitted morbidity reports to the Public Health Service and in the following 7 years the numbers ranged from 11 to 29. After the 1916 epidemic, Lavinder, Freeman, and Frost published a summary of morbidity and mortality for the period 1909-16 which incorporated data from a number of States not included in the earlier national summaries. For the years 1909-15, they obtained additional State morbidity reports and also mortality reports for some States in which no morbidity data were available. For the latter, estimates of cases were made from reported poliomyelitis deaths, assuming a case fatality rate of 20 percent. For States in which only certain cities were in the registration area, deaths for the entire State were estimated from those in the registration areas. Since Lavinder, Freeman, and Frost had noted that in States for which registration was complete, the urban death rate was lower than the rural rate and that a case fatality as high as 20 percent occurred only rarely, they believed that error in their estimates had been in the direction of underestimation. Because of the care which went into this study, their figures for annual incidence of poliomyelitis in the Nation for 1909-16 are quoted below :

\begin{tabular}{|c|c|}
\hline Year & $\begin{array}{c}\text { Cases per } 100,000 \\
\text { population }\end{array}$ \\
\hline $1909_{-}$ & 6.9 \\
\hline 1910 & 13.3 \\
\hline 1911 & -9.5 \\
\hline 1912 & $\ldots-8.5$ \\
\hline 1913 & $\ldots 6.6$ \\
\hline 1914 & $\ldots-1$ \\
\hline 1915 & $-\quad 5.1$ \\
\hline
\end{tabular}

During the 5 years following the 1910 outbreaks, the estimated national rates declined. In these years the largest outbreaks took place in 1912, when New York reported 1,108 cases and California, 531. These were the only instances in which a State reported more than 500 cases, although Massachusetts, New York, Pennsylvania, and Virginia reported from 100 to 500 cases annually, and Illinois and Ohio reported from 100 to 500 cases in 4 of the 5 years.

The great epidemic of 1916, although leading to highest rates in the northeastern States, also
Table 1. States reporting 20 or more poliomyelitis cases per 100,000 population in 1916

\begin{tabular}{|c|c|c|c|c|c|}
\hline Eastern States & $\begin{array}{l}\text { Num- } \\
\text { ber of } \\
\text { cases }\end{array}$ & $\begin{array}{l}\text { Case } \\
\text { rate }\end{array}$ & $\begin{array}{l}\text { Central and } \\
\text { western } \\
\text { States }\end{array}$ & $\begin{array}{l}\text { Num- } \\
\text { ber of } \\
\text { cases }\end{array}$ & $\begin{array}{l}\text { Case } \\
\text { rate }\end{array}$ \\
\hline $\begin{array}{l}\text { New Jersey } \\
\text { New York } \\
\text { Connecticut } \\
\text { Massachusetts } \\
\text { Rhode Island } \\
\text { Delaware } \\
\text { Pennsylvania } \\
\text { Maryland } \\
\text { Maine }\end{array}$ & \begin{tabular}{|r|}
4,055 \\
13,223 \\
951 \\
1,926 \\
222 \\
79 \\
2,181 \\
352 \\
149
\end{tabular} & \begin{tabular}{r|}
138 \\
129 \\
76 \\
52 \\
36 \\
37 \\
26 \\
26 \\
19
\end{tabular} & $\begin{array}{l}\text { Minnesota } \\
\text { Michigan } \\
\text { Montana.- } \\
\text { Wisconsin }\end{array}$ & $\begin{array}{r}909 \\
616 \\
94 \\
475\end{array}$ & $\begin{array}{l}40 \\
20 \\
20 \\
19\end{array}$ \\
\hline
\end{tabular}

Source: Lavinder, Freeman, and Frost (1).

struck severely in the north central area and in Montana. States with rates of approximately 20 per 100,000 population or larger are listed in table 1.

For the year 1916, Lavinder, Freeman, and Frost obtained morbidity reports from all but four States, amounting to a total of 29,061 cases. From these they estimated the national rate to have been 28.5 cases per 100,000 population.

Table 2. Annual poliomyelitis case and death rates, United States, ${ }^{1}$ 1917-31

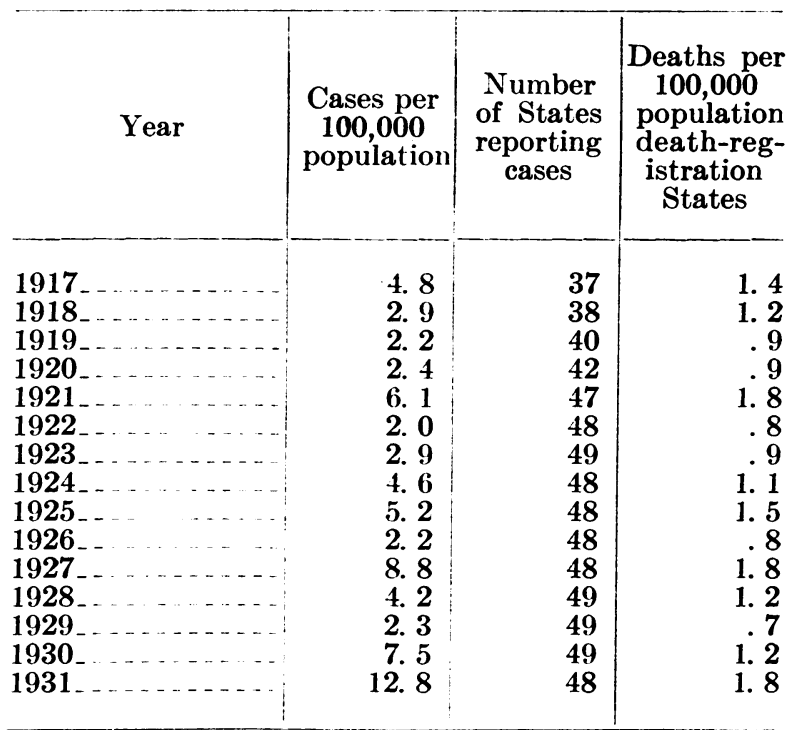

1 Includes District of Columbia as a separate reporting unit. States reporting cases not necessarily the same as those reporting deaths.

Sources: Cases, Notifiable Diseases, Annual Reports, Public Health Service; Deaths, Death-Registration States, Annual Reports, Vital Statistics of the United States. 
The total number of cases in the District of Columbia and the 27 States which reported to the Public Health Service was 27,363. Among these States, the average rate was 41 cases per 100,000 population.

\section{Years 1917-31}

After 1916, no additional efforts were made to obtain complete information on reported cases of poliomyelitis. Annual case rates for the Nation, computed on the basis of the populations of those States submitting reports, and death rates for the death-registration States are shown in table 2. The period seems to have been one of generally low incidence of poliomyelitis. National rates varied from 2.0 in 1922 to 8.8 in 1927 , except for the epidemic year of 1931, when the rate reached 12.8. Despite the generally low national rates, outbreaks of moderate size were reported by a number of States.

In 1917, the rate in Vermont was three times the 1916 rate. In the early and middle 1920 's, the north central and western States of Minnesota, North Dakota, Montana, and Washington reported the highest rates in the country. In 1927 and 1928 a dozen States, ranging from Maine to California, reported from 21 to 49 cases per 100,000 population. The 1931 outbreak was largely concentrated in the New England and Middle Atlantic States, and in Michigan in the midwest. The highest rates occurred in Connecticut (69.6) and in New York (48.2).

\section{Years 1932-52}

Annual rates for the United States during the period 1932-52 are shown in table 3. After the 1931 outbreak, the annual national rates did not exceed 10 cases per 100,000 population until 1944. In 1943 the case rate was 9.3, the highest since 1931, and in the succeeding years rose to successively higher levels, until in 1952 both the case rate (36.9) and the estimated death rate (2.0) were higher than in any year since the 1916 epidemic. With the marked upward trend in the morbidity rate, there has been a slight but definite increase in the mortality rate. This has resulted in a progressive decline in the ratio of reported deaths to cases from 14.0 percent in the period 1932-36 to 5.8 percent in the period 1947-51.
Table 3. Poliomyelitis case rates, death rates, and their ratios, United States, 1932-52 ${ }^{1}$

\begin{tabular}{|c|c|c|c|c|c|c|}
\hline \multirow{2}{*}{ Year } & \multicolumn{2}{|c|}{$\begin{array}{c}\text { Rates per } \\
100,000 \\
\text { population }\end{array}$} & \multirow{2}{*}{$\begin{array}{l}\text { Ratio of } \\
\text { death } \\
\text { rate to } \\
\text { case } \\
\text { rate } \\
\text { (per- } \\
\text { cent) }\end{array}$} & \multirow{2}{*}{$\begin{array}{c}\text { Aver- } \\
\text { age } \\
\text { case } \\
\text { rate }\end{array}$} & \multirow{2}{*}{$\begin{array}{c}5- \\
\text { year } \\
\text { death } \\
\text { rate }\end{array}$} & \multirow{2}{*}{$\begin{array}{l}\text { Ratio of } \\
\text { death } \\
\text { rate to } \\
\text { case } \\
\text { rate } \\
\text { (per- } \\
\text { cent) }\end{array}$} \\
\hline & Cases & Deaths & & & & \\
\hline $\begin{array}{l}1932 \\
1933 \\
1934 \\
1935 \\
1936\end{array}$ & $\begin{array}{l}3.0 \\
4.0 \\
5.9 \\
8.5 \\
3.5\end{array}$ & $\begin{array}{l}0.7 \\
.6 \\
.7 \\
.8 \\
.6\end{array}$ & $\begin{array}{r}23.3 \\
15.0 \\
11.9 \\
9.4 \\
17.1\end{array}$ & 5. 0 & 0. 7 & 14.0 \\
\hline $\begin{array}{l}1937 \\
1938 \\
1939 \\
1940 \\
1941\end{array}$ & $\begin{array}{l}7.4 \\
1.3 \\
5.6 \\
7.4 \\
6.8\end{array}$ & $\begin{array}{l}1.1 \\
.4 \\
.6 \\
.8 \\
.6\end{array}$ & $\begin{array}{r}14.9 \\
30.8 \\
10.7 \\
10.8 \\
8.8\end{array}$ & 5. 7 & .7 & 12. 3 \\
\hline $\begin{array}{l}1942 \\
1943 \\
1944 \\
1945 \\
1946\end{array}$ & $\begin{array}{r}3.0 \\
9.3 \\
14.3 \\
10.3 \\
18.4\end{array}$ & $\begin{array}{r}.4 \\
.9 \\
1.0 \\
.9 \\
1.3\end{array}$ & $\begin{array}{r}13.3 \\
9.7 \\
7.0 \\
8.7 \\
7.1\end{array}$ & 11. 1 & .9 & 8. 1 \\
\hline $\begin{array}{l}1947 \\
1948 \\
1949 \\
1950 \\
1951\end{array}$ & $\begin{array}{r}7.5 \\
19.1 \\
28.4 \\
22.0 \\
18.6\end{array}$ & $\begin{array}{r}.4 \\
1.3 \\
1.8 \\
1.3 \\
.9\end{array}$ & $\begin{array}{l}5.3 \\
6.8 \\
6.3 \\
5.9 \\
4.8\end{array}$ & 19. 1 & 1.1 & 5. 8 \\
\hline 1952 & 36.9 & 22.0 & 5. 4 & & & \\
\hline
\end{tabular}

1 Case and death rates based on population of States reporting both cases and deaths.

21952 death rate estimated from 10-percent national sample of the National Office of Vital Statistics, January through November 1952.

The morbidity rate for 1952 falls between the two estimates (see above) for 1916, while the estimated mortality rate for 1952 is only onefifth as great as the 1916 death rate of 10.5 per 100,000 . The question of whether or not the 1952 epidemic was more severe than that of 1916 is obscured by several factors relating to the population bases used in determining the rates. In 1952 reports of cases and deaths were available from all States, whereas for 1916 two estimates of the morbidity rate are available, but neither of the populations on which these are based is the same as that of the 26 deathregistration States for which the mortality rate was 10.5 per 100,000 . Also, the 1916 population of the death-registration States coincided closely with the populations severely affected by the epidemic, while the 1952 estimated death rate of 2.0 per 100,000 includes populations not in epidemic areas. In addition to these factors, 
Figure 2. Poliomyelitis morbidity-average 5-year rates, major geographic divisions of the United States, 1932-36, 1937-41, 1942-46, 1947-51.
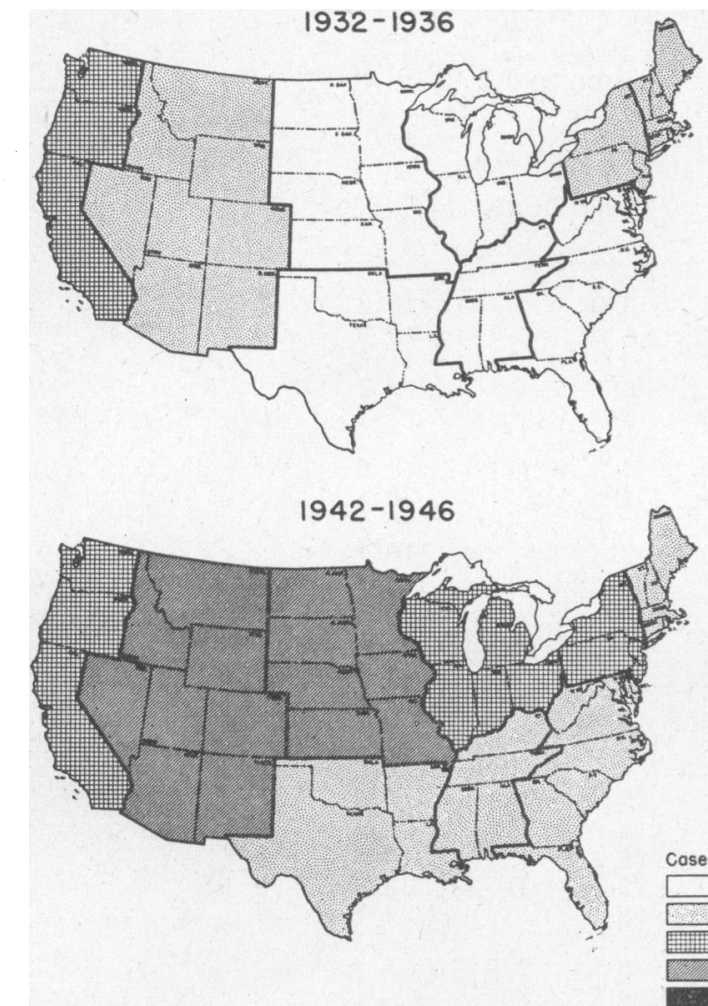
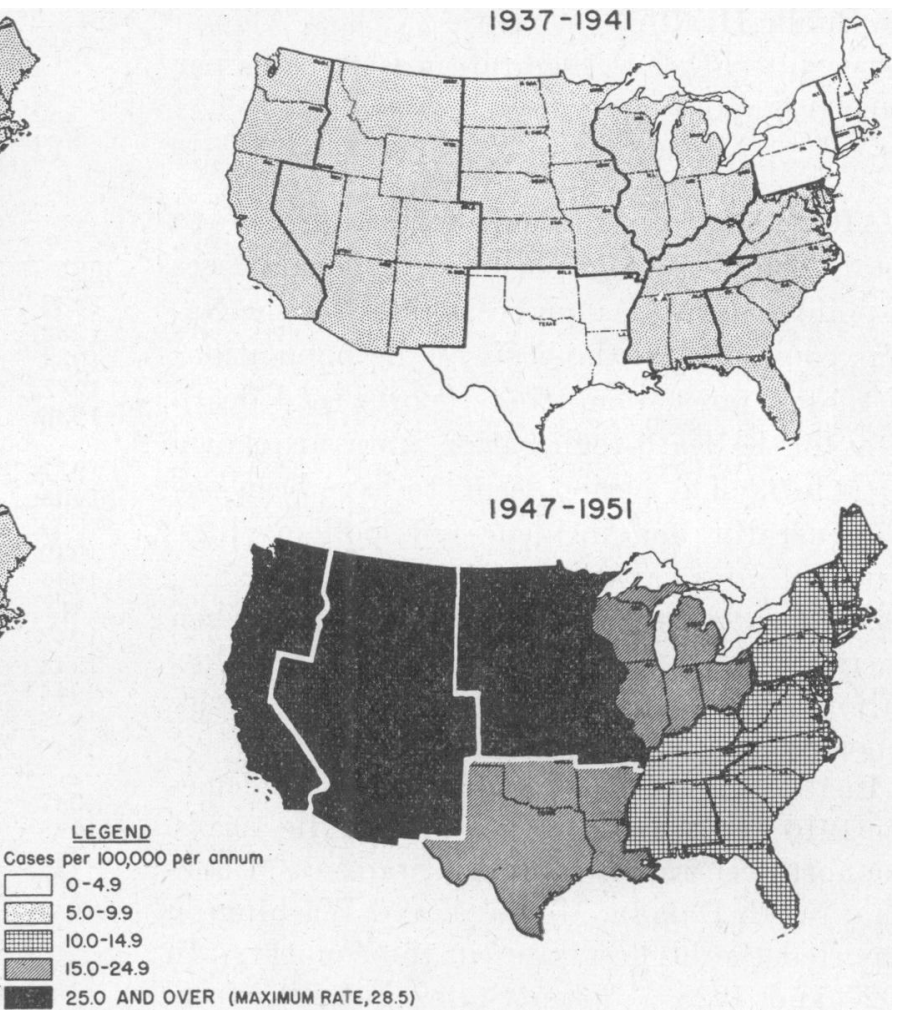

others must be considered: for example, improvement in completeness and accuracy of morbidity reporting; and improvement in treatment, presumably resulting in lowered case fatality rates.

\section{Geographic Distribution}

The geographic distribution of poliomyelitis in the United States during the last 20 years is described for the nine major geographic divisions of the country from two approaches: average incidence in successive 5-year periods and variation in annual incidence. Each method gives emphasis to different aspects of secular changes in geographic distribution of the disease.

\section{Average Incidence}

Aycock (3), in studying distribution of poliomyelitis in the United States during the period 1910-27, and later Wells (4), in a study of the period 1915-29, came to the conclusion that incidence in the northern States had been distinctly greater than that in the southern portion of the country. Both of these studies included the 1916 epidemic, which caused the average rates to be heavily weighted by this single northern epidemic. Collins (5), examining data for the period 1930-45 noted that little poliomyelitis had been reported from the three southern divisions prior to 1935 but that subsequently they experienced "some rather large epidemics." Gilliam, Hemphill, and Gerende $(6,7)$, in a study of county rates during the period 1932-46, came to a similar conclusion. In their study, the average annual rate in the period 1932-46 for northern counties was 7.6 and for southern counties, 6.4. However, in large urban counties of over 500,000 population, average rates were lower in northern than in southern counties. In counties under 100,000 population, the reverse was truethe average rates were higher in northern than in southern counties. The period was one of generally low incidence, except for the later years, $1944-46$. In the present study, examination of rates for the 20 years 1932-51, in successive 5-year periods, did not seem to reflect consistent geographic localization (fig. 2). 
During the first 10 years $(1932-41)$ of the period, average incidence was remarkably uniform over 5 of the 9 major geographic divisions (table 4) ranging from 5.1 to 5.9 per 100,000 population. One of these five was the East South Central division. The lowest rates occurred in the West South Central and South Atlantic States (3.0 and 4.6) ; the highest rates occurred in the Mountain and Pacific divisions (6.3 and 10.7).

During the first half $(1942-46)$ of the next decade, the northwestern divisions had rates which were generally higher than those of the South Atlantic, East South Central, and West South Central divisions. However, within the eastern and southern regions, the average 5-year rates for the New England States was somewhat lower than that of the West South Central States.

In the next 5 years (1947-51), a different configuration was displayed, the divisions west of the Mississippi having rates considerably higher than those east of the Mississippi. Average 5-year rates were nearly the same, 13.4, 14.0, 14.1, and 14.5 per 100,000 respectively, in the East South Central, South Atlantic, New England, and Middle Atlantic States. In intermediate position were the East North Central and West South Central States with average rates of 20.4 and 22.2 per 100,000 population.

The West North Central, Mountain, and Pacific States, with average 5-year rates, respec- tively, of $28.5,28.5$, and 26.1 , were markedly higher than the rest of the country. For individual States, 5-year average rates are shown in table 5. It should be noted that the 5-year average rates varied considerably among the States in each division.

Over the past 20 years geographic differentials in incidence between regions of the United States have existed. In the long run, these differentials have tended to become equalized, although over rather extended time periods. Over moderate periods of time, one region may experience severe epidemics alternating with periods of very low incidence, while another region may be experiencing a succession of epidemics. As a result, even longtime averages are greatly influenced by a few severe epidemic years.

The average 20-year rates for western geographic divisions, which depart most from average rates of the remainder of the country, have been greatly influenced by the experience of recent years. The marked recent rise in the western States generally, and particularly, in the southwest, suggests that it may be of interest to watch the future trend in the southeastern States which have recently had only moderate increases in their annual rates.

\section{Changing Epidemic Patterns}

Interpretation of geographic differences calls for consideration not only of average incidence,

Table 4. Average poliomyelitis case rates in each division of the United States, 1932-51, by 5-year, 10-year and 20-year periods ${ }^{1}$

\begin{tabular}{|c|c|c|c|c|c|c|c|}
\hline \multirow{2}{*}{ Division } & \multicolumn{4}{|c|}{ 5-year mean } & \multicolumn{2}{|c|}{ 10-year mean } & \multirow{2}{*}{$\begin{array}{c}\begin{array}{c}20 \cdot \text { year } \\
\text { mean }\end{array} \\
\begin{array}{c}1932 \\
\text { through } \\
1951\end{array}\end{array}$} \\
\hline & $\begin{array}{c}1932 \\
\text { through } \\
1936\end{array}$ & $\begin{array}{c}1937 \\
\text { through } \\
1941\end{array}$ & $\begin{array}{c}1942 \\
\text { through } \\
1946\end{array}$ & $\begin{array}{c}1947 \\
\text { through } \\
1951\end{array}$ & $\begin{array}{c}1932 \\
\text { through } \\
1941\end{array}$ & $\begin{array}{c}1942 \\
\text { through } \\
1951\end{array}$ & \\
\hline $\begin{array}{l}\text { New England } \\
\text { Middle Atlantic } \\
\text { East North Central } \\
\text { South Atlantic } \\
\text { East South Central... } \\
\text { West South Central } \\
\text { West North Central } \\
\text { Mountain } \\
\text { Pacific. }\end{array}$ & $\begin{array}{r}\text { 8. } 4 \\
6.0 \\
\text { 3. } 5 \\
\text { 3. } 8 \\
\text { 4. } 2 \\
\text { 1. } 5 \\
2.9 \\
\text { 5. } 5 \\
\text { 14. } 2\end{array}$ & $\begin{array}{l}\text { 3. } 4 \\
\text { 4. } 2 \\
6.7 \\
\text { 5. } 3 \\
6.3 \\
\text { 4. } 6 \\
\text { 8. } 1 \\
\text { 7. } 1 \\
\text { 7. } 2\end{array}$ & $\begin{aligned} \text { 8. } 7 \\
11.6 \\
11.1 \\
6.4 \\
6.8 \\
9.9 \\
18.9 \\
16.6 \\
14.0\end{aligned}$ & $\begin{array}{l}\text { 14. } 1 \\
14.5 \\
20.4 \\
14.0 \\
13.4 \\
22.2 \\
28.5 \\
28.5 \\
26.1\end{array}$ & $\begin{array}{r}\text { 5. } 9 \\
5.1 \\
5.1 \\
\text { 4. } 6 \\
5.2 \\
\text { 3. } 0 \\
\text { 5. } 5 \\
6.3 \\
10.7\end{array}$ & $\begin{array}{l}\text { 11. } 4 \\
13.1 \\
15.7 \\
10.2 \\
10.1 \\
16.0 \\
23.7 \\
22.5 \\
20.1\end{array}$ & $\begin{aligned} 8.6 \\
9.1 \\
10.4 \\
7.4 \\
7.7 \\
9.5 \\
14.6 \\
14.4 \\
15.4\end{aligned}$ \\
\hline
\end{tabular}

1 Average numbers of cases per 100,000 population based on annual reports in Notifiable Diseases, Public Health Service. 
Figure 3. Poliomyelitis morbidity in major geographic divisions of the United States, reported cases per 100,000 population per annum, 1932-52.

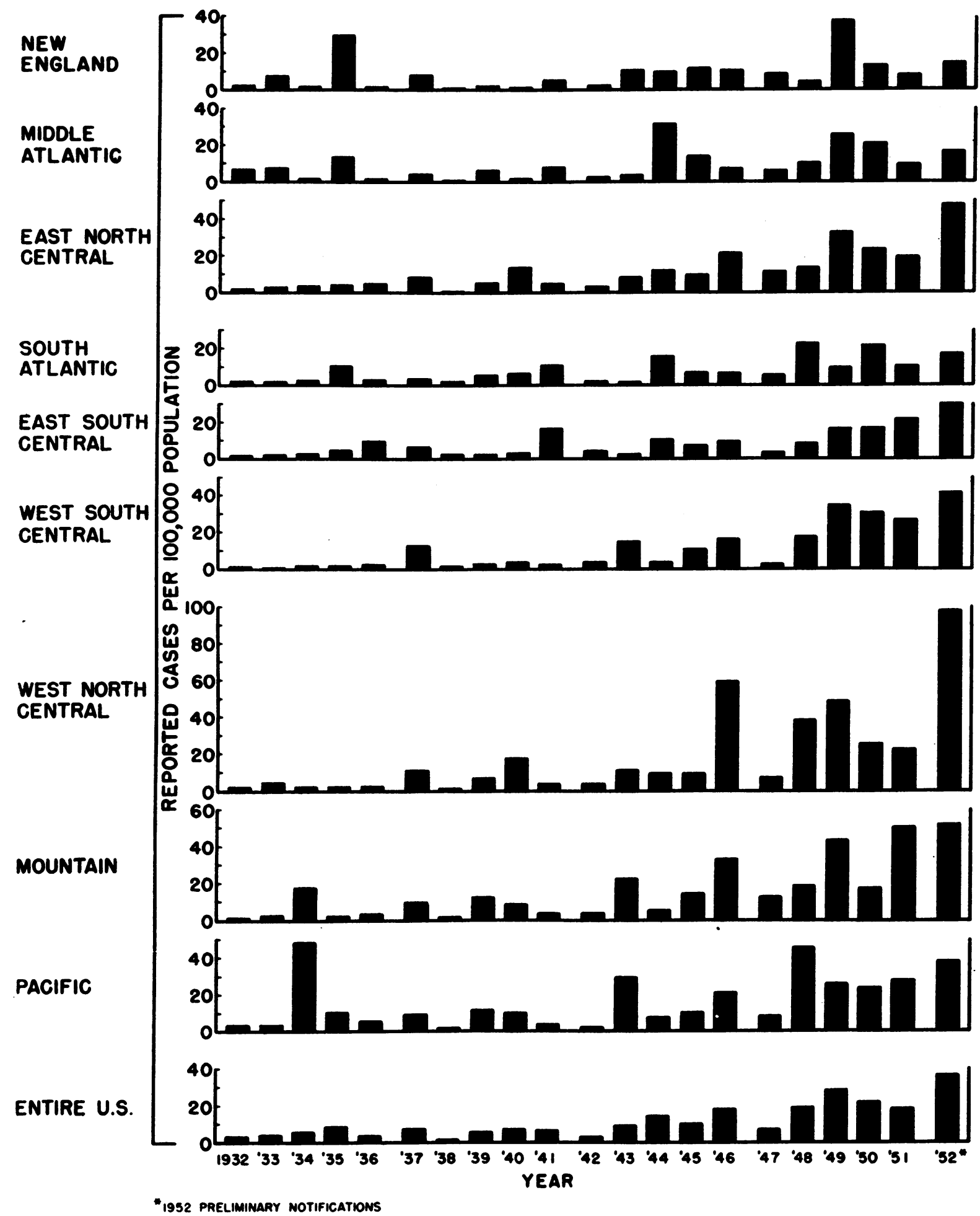


but also of shifting centers of epidemic concentration. Configurations of States swept by epidemics change from year to year as the areas of greatest incidence move from one region to another. Regions swept by an epidemic at one time dissolve into components which re-form in new configurations as a succeeding epidemic wave develops.

The annual concentrations of epidemics have been illustrated excellently in the series of maps prepared for many years by Dr. Carl C. Dauer. The first maps in this series were published in Public Health Reports (16) and included the years 1933-37. For subsequent years the maps have been published yearly in an annual review of reported poliomyelitis in the United States. The changing centers of epidemic concentration illustrated in detail in Dauer's series of maps can also be recognized in the annual poliomyelitis rates (fig. 3 and table 6) for each division of the United States.

From 1932 through 1939, three distinctive patterns of epidemic outbreaks emerge: The Mountain and Pacific States, which experienced their most severe outbreak in 1934; the New England, Middle Atlantic, and South Atlantic States in 1935; the East South Central States in 1936 and 1937; and the remaining three central divisions in 1937.

From 1940 through 1948, severe epidemics did not strike east and west of the Mississippi in the same years, except for States in the East North Central division, which experienced epidemics coincident in some years with States east of the Mississippi; in other years, with western States. In 1944, the East North Central States reflected the eastern epidemic; and in 1946 , the western outbreak.

In 1949, all divisions except the South Atlantic experienced severe outbreaks of poliomyelitis. In the latter division, 1948 and 1950 were years of greater severity. In 1950, rates were moderately high in all areas.

In 1951, the national rate was lower than in the preceding 3 years. The highest rate was recorded in the Mountain division. In the severe epidemic of 1952, a record rate of 98.0 occurred in the West North Central States. Record rates were also reported from the other three central divisions and from the Mountain
Table 5. Reported cases of poliomyelitis, per 100,000 population, by States, 1932-51 ${ }^{1}$

\begin{tabular}{|c|c|c|c|c|}
\hline \multirow{2}{*}{ State } & \multicolumn{4}{|c|}{ 5-year averages } \\
\hline & $\begin{array}{c}1932- \\
36\end{array}$ & $\begin{array}{c}1937- \\
41\end{array}$ & $\begin{array}{c}1942- \\
46\end{array}$ & $\begin{array}{c}1947- \\
51\end{array}$ \\
\hline $\begin{array}{l}\text { New England: } \\
\text { Maine } \\
\text { New Hampshire } \\
\text { Vermont_. } \\
\text { Massachusetts. } \\
\text { Rhode Island } \\
\text { Connecticut. }\end{array}$ & $\begin{array}{r}8.6 \\
4.2 \\
9.3 \\
9.0 \\
11.3 \\
6.5\end{array}$ & \begin{tabular}{l|} 
5. 0 \\
3. 3 \\
6. 4 \\
3. 1 \\
2. 4 \\
3. 3
\end{tabular} & $\begin{array}{r}4.8 \\
12.4 \\
13.0 \\
7.3 \\
8.2 \\
10.7\end{array}$ & $\begin{array}{l}\text { 14. } 9 \\
\text { 13. } 9 \\
15.1 \\
13.5 \\
10.6 \\
17.1\end{array}$ \\
\hline $\begin{array}{l}\text { Middle Atlantic: } \\
\text { New York } \\
\text { New Jersey } \\
\text { Pennsylvania }\end{array}$ & $\begin{array}{l}\text { 7. } 7 \\
5.9 \\
4.1\end{array}$ & $\begin{array}{l}\text { 4. } 7 \\
\text { 4. } 0 \\
\text { 3. } 6\end{array}$ & $\begin{array}{r}14.6 \\
9.5 \\
5.6\end{array}$ & $\begin{array}{r}18.5 \\
16.5 \\
8.0\end{array}$ \\
\hline $\begin{array}{l}\text { East North Central: } \\
\text { Ohio } \\
\text { Indiana._. } \\
\text { Illinois_. } \\
\text { Michigan } \\
\text { Wisconsin }\end{array}$ & $\begin{array}{l}3.4 \\
1.5 \\
4.0 \\
4.8 \\
2.4\end{array}$ & $\begin{array}{r}5.5 \\
6.0 \\
5.2 \\
11.1 \\
6.7\end{array}$ & $\begin{aligned} 7.4 \\
6.6 \\
15.3 \\
8.9 \\
14.7\end{aligned}$ & $\begin{array}{l}\text { 18. } 8 \\
14.3 \\
19.4 \\
25.0 \\
25.6\end{array}$ \\
\hline 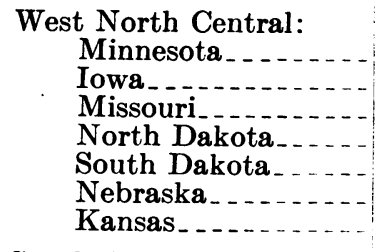 & $\begin{array}{l}\text { 5. } 6 \\
\text { 2. } 2 \\
\text { 1. } 4 \\
\text { 4. } 6 \\
\text { 3. } 7 \\
\text { 1. } 8 \\
\text { 3. } 3\end{array}$ & $\begin{array}{r}11.0 \\
11.4 \\
4.3 \\
\text { 3. } 1 \\
6.5 \\
7.5 \\
9.8\end{array}$ & $\begin{array}{l}29.5 \\
11.1 \\
10.6 \\
19.2 \\
13.6 \\
17.2 \\
23.7\end{array}$ & $\begin{array}{l}\text { 32. } 2 \\
\text { 34. } 4 \\
\text { 14. } 8 \\
25.3 \\
51.7 \\
\text { 37. } 6 \\
26.0\end{array}$ \\
\hline $\begin{array}{l}\text { South Atlantic: } \\
\text { Delaware } \\
\text { Maryland } \\
\text { District of Columbia } \\
\text { Virginia } \\
\text { West Virginia } \\
\text { North Carolina } \\
\text { South Carolina } \\
\text { Georgia } \\
\text { Florida }\end{array}$ & $\begin{array}{r}2.2 \\
2.9 \\
5.5 \\
7.4 \\
3.6 \\
5.1 \\
2.1 \\
2.2 \\
.9\end{array}$ & $\begin{array}{l}\text { 3. } 4 \\
\text { 4. } 2 \\
5.0 \\
4.3 \\
9.1 \\
2.9 \\
\text { 7. } 4 \\
7.1 \\
\text { 4. } 6\end{array}$ & $\begin{array}{r}12.4 \\
7.9 \\
10.7 \\
9.1 \\
4.6 \\
6.9 \\
3.7 \\
2.9 \\
7.9\end{array}$ & $\begin{aligned} 21.9 \\
12.0 \\
13.9 \\
15.7 \\
13.5 \\
20.7 \\
10.6 \\
9.7 \\
11.3\end{aligned}$ \\
\hline $\begin{array}{l}\text { East South Central: } \\
\text { Kentucky } \\
\text { Tennessee } \\
\text { Alabama } \\
\text { Mississippi }\end{array}$ & $\begin{array}{l}4.7 \\
5.2 \\
4.2 \\
2.3\end{array}$ & $\begin{array}{l}\text { 5. } 5 \\
5.5 \\
8.2 \\
6.0\end{array}$ & $\begin{array}{l}8.6 \\
6.1 \\
5.1 \\
6.0\end{array}$ & $\begin{array}{r}14.0 \\
14.4 \\
9.8 \\
15.6\end{array}$ \\
\hline $\begin{array}{l}\text { Test South Central: } \\
\text { Arkansas__._. } \\
\text { Louisiana } \\
\text { Oklahoma } \\
\text { Texas }\end{array}$ & $\begin{array}{l}1.2 \\
2.2 \\
1.5 \\
1.2\end{array}$ & $\begin{array}{l}\text { 5. } 3 \\
\text { 3. } 5 \\
6.7 \\
\text { 3. } 9\end{array}$ & $\begin{array}{r}7.7 \\
6.5 \\
11.4 \\
10.8\end{array}$ & $\begin{array}{l}21.1 \\
12.7 \\
26.0 \\
24.0\end{array}$ \\
\hline $\begin{array}{l}\text { Tountain: } \\
\text { Montana } \\
\text { Idaho } \\
\text { Wyoming } \\
\text { Colorado_... } \\
\text { New Mexico } \\
\text { Arizona_.. } \\
\text { Utah } \\
\text { Nevada. }\end{array}$ & $\begin{array}{l}\text { 13. } 3 \\
\text { 8. } 4 \\
\text { 3. } 4 \\
\text { 1. } 5 \\
\text { 3. } 3 \\
\text { 9. } 2 \\
\text { 2. } 1 \\
\text { 5. } 1\end{array}$ & $\begin{array}{l}\text { 6. } 9 \\
5.4 \\
\text { 8. } \\
\text { 7. } 8 \\
6.9 \\
6.4 \\
\text { 8. } 9 \\
\text { 1. } 9\end{array}$ & $\begin{aligned} 10.1 \\
3.9 \\
15.3 \\
23.9 \\
10.8 \\
12.6 \\
28.1 \\
9.4\end{aligned}$ & $\begin{array}{l}12.9 \\
44.3 \\
33.3 \\
32.8 \\
18.0 \\
23.5 \\
35.8 \\
16.5\end{array}$ \\
\hline $\begin{array}{l}\text { cific: } \\
\text { Washington } \\
\text { Oregon } \\
\text { California }\end{array}$ & $\begin{array}{r}12.7 \\
4.5 \\
15.9\end{array}$ & $\begin{array}{l}\text { 7. } 6 \\
\text { 5. } 3 \\
\text { 7. } 4\end{array}$ & $\begin{array}{l}14.5 \\
14.2 \\
15.5\end{array}$ & $\begin{array}{l}19.3 \\
20.9 \\
29.5\end{array}$ \\
\hline
\end{tabular}

1 Preliminary notifications. 
Table 6. Cases of reported poliomyelitis in major geographic divisions, 1932-52

\begin{tabular}{|c|c|c|c|c|c|c|c|c|c|c|}
\hline \multirow[b]{2}{*}{ Year } & \multicolumn{10}{|c|}{ Cases per 100,000 population } \\
\hline & $\begin{array}{c}\text { New } \\
\text { England }\end{array}$ & $\begin{array}{l}\text { Middle } \\
\text { Atlantic }\end{array}$ & $\begin{array}{c}\text { East } \\
\text { North } \\
\text { Central }\end{array}$ & $\begin{array}{c}\text { West } \\
\text { North } \\
\text { Central }\end{array}$ & $\begin{array}{c}\text { South } \\
\text { Atlantic }\end{array}$ & $\begin{array}{c}\text { East } \\
\text { South } \\
\text { Central }\end{array}$ & $\begin{array}{c}\text { West } \\
\text { South } \\
\text { Central }\end{array}$ & $\begin{array}{c}\text { Moun- } \\
\text { tain }\end{array}$ & Pacific & $\begin{array}{l}\text { United } \\
\text { States }\end{array}$ \\
\hline $\begin{array}{l}1932 \\
1933 \ldots \\
1934 \\
1935 \\
1936\end{array}$ & $\begin{array}{r}2.3 \\
7.1 \\
1.6 \\
29.3 \\
1.5\end{array}$ & $\begin{array}{r}6.7 \\
7.5 \\
1.5 \\
13.2 \\
1.3\end{array}$ & $\begin{array}{l}\text { 1. } 9 \\
\text { 3. } 0 \\
\text { 3. } 7 \\
\text { 4. } 1 \\
\text { 4. } 9\end{array}$ & $\begin{array}{l}2.3 \\
4.9 \\
2.5 \\
2.2 \\
2.7\end{array}$ & \begin{tabular}{r|}
2.0 \\
1.8 \\
2.2 \\
10.2 \\
2.8
\end{tabular} & $\begin{array}{l}1.8 \\
2.0 \\
2.6 \\
4.9 \\
9.7\end{array}$ & $\begin{array}{l}\text { 1. } 1 \\
.4 \\
1.7 \\
1.8 \\
\text { 2. } 3\end{array}$ & $\begin{array}{r}1.4 \\
2.8 \\
\text { 17. } 9 \\
2.2 \\
\text { 3. } 2\end{array}$ & $\begin{array}{r}3.5 \\
3.5 \\
48.1 \\
10.5 \\
5.6\end{array}$ & $\begin{array}{l}\text { 3. } 0 \\
\text { 4. } 0 \\
\text { 5. } 9 \\
\text { 8. } 5 \\
\text { 3. } 5\end{array}$ \\
\hline $\begin{array}{l}1937 \ldots \ldots \\
1938 \ldots \\
1939 \\
1940 \\
1941\end{array}$ & $\begin{array}{l}8.0 \\
.9 \\
1.8 \\
1.2 \\
5.2\end{array}$ & $\begin{array}{l}\text { 4. } 1 \\
.9 \\
6.2 \\
1.6 \\
8.0\end{array}$ & $\begin{array}{r}8.3 \\
1.0 \\
5.3 \\
13.7 \\
5.0\end{array}$ & $\begin{array}{r}11.1 \\
1.3 \\
7.0 \\
17.5 \\
3.8\end{array}$ & $\begin{array}{r}\text { 3. } 1 \\
1.8 \\
5.1 \\
6.1 \\
10.4\end{array}$ & $\begin{array}{r}6.6 \\
2.3 \\
2.6 \\
3.4 \\
16.5\end{array}$ & $\begin{array}{r}12.4 \\
1.4 \\
2.8 \\
3.8 \\
2.4\end{array}$ & $\begin{array}{r}9.8 \\
1.6 \\
12.1 \\
8.7 \\
3.5\end{array}$ & $\begin{array}{r}9.1 \\
1.6 \\
11.4 \\
9.9 \\
3.9\end{array}$ & $\begin{array}{l}\text { 7. } 4 \\
\text { 1. } 3 \\
\text { 5. } 6 \\
\text { 7. } 4 \\
\text { 6. } 8\end{array}$ \\
\hline $\begin{array}{l}1942 \\
1943 \\
1944 \\
1945 \\
1946\end{array}$ & $\begin{array}{r}2.1 \\
10.5 \\
9.6 \\
11.3 \\
10.1\end{array}$ & $\begin{array}{r}2.4 \\
3.4 \\
31.1 \\
13.9 \\
7.1\end{array}$ & $\begin{array}{r}3.5 \\
8.5 \\
12.2 \\
9.8 \\
21.5\end{array}$ & $\begin{array}{r}4.0 \\
11.5 \\
9.9 \\
9.8 \\
59.5\end{array}$ & $\begin{array}{r}2.0 \\
1.3 \\
15.2 \\
6.9 \\
6.7\end{array}$ & $\begin{array}{r}4.1 \\
2.3 \\
10.8 \\
7.1 \\
9.5\end{array}$ & $\begin{array}{r}3.7 \\
14.9 \\
3.8 \\
10.7 \\
16.2\end{array}$ & $\begin{array}{r}\text { 3. } 8 \\
22.4 \\
5.1 \\
14.0 \\
\text { 37. } 7\end{array}$ & $\begin{array}{r}2.3 \\
29.3 \\
7.5 \\
10.1 \\
21.0\end{array}$ & $\begin{array}{r}\text { 3. } 0 \\
9.3 \\
14.3 \\
10.3 \\
18.4\end{array}$ \\
\hline $\begin{array}{l}1947 \ldots \ldots \\
1948 \ldots \\
1949 \ldots \ldots \\
1950 \ldots \ldots \\
1951 \ldots \ldots\end{array}$ & $\begin{array}{r}\text { 8. } 2 \\
\text { 4. } 3 \\
\text { 37. } 1 \\
\text { 13. } 0 \\
\text { 7. } 9\end{array}$ & $\begin{array}{r}6.9 \\
10.1 \\
25.4 \\
20.7 \\
9.5\end{array}$ & $\begin{array}{l}11.8 \\
13.8 \\
32.8 \\
23.8 \\
19.6\end{array}$ & $\begin{array}{l}\text { 7. } 2 \\
38.3 \\
48.9 \\
25.4 \\
22.8\end{array}$ & $\begin{array}{r}5.6 \\
22.7 \\
9.5 \\
21.8 \\
10.4\end{array}$ & $\begin{array}{r}3.7 \\
8.6 \\
16.5 \\
16.7 \\
21.5\end{array}$ & $\begin{array}{r}2.7 \\
17.2 \\
34.3 \\
30.2 \\
26.7\end{array}$ & $\begin{array}{l}12.6 \\
18.9 \\
43.3 \\
17.2 \\
50.4\end{array}$ & $\begin{array}{r}8.3 \\
45.3 \\
25.8 \\
23.4 \\
27.5\end{array}$ & $\begin{array}{r}7.5 \\
19.1 \\
28.4 \\
22.0 \\
18.6\end{array}$ \\
\hline 1952 & 14. 2 & 16. 1 & 47. 7 & 98. 0 & 17.0 & 30.0 & 41. 3 & 51. 8 & 38. 1 & 36. 9 \\
\hline
\end{tabular}

Source: Notifiable Diseases 1932-50 and Annual Summary in Public Health Reports, May 25, 1951, pp. 677-683. National Office of Vital Statistics: Weekly Morbidity Reports, 1952.

States. The Pacific division experienced the third highest rate in its history. Along the eastern seaboard rates were well below the national average, although moderately high in comparison with many previous years.

\section{Seasonal Distribution}

If the reported cases of poliomyelitis in the United States for each month are averaged for a few years, the resulting curve rises slightly in

Table 7. Seasonal incidence of poliomyelitis, United States, 1942-52

[Reported cases per 100,000 population, each month, adjusted to annual base]

\begin{tabular}{|c|c|c|c|c|c|c|c|c|c|c|c|c|c|}
\hline Year & $\begin{array}{c}\text { Janu- } \\
\text { ary }\end{array}$ & $\begin{array}{c}\text { Febru- } \\
\text { ary }\end{array}$ & March & April & May & June & July & $\begin{array}{l}\text { Au- } \\
\text { gust }\end{array}$ & $\begin{array}{l}\text { Sep- } \\
\text { tem- } \\
\text { ber }\end{array}$ & $\begin{array}{l}\text { Oc- } \\
\text { tober }\end{array}$ & $\begin{array}{l}\text { No- } \\
\text { vem- } \\
\text { ber }\end{array}$ & $\begin{array}{c}\text { De- } \\
\text { cem- } \\
\text { ber }\end{array}$ & $\begin{array}{l}\text { An- } \\
\text { nual } \\
\text { Rate }\end{array}$ \\
\hline $\begin{array}{l}1942 \ldots 1 \\
1943 \\
1944 \\
1945 \\
1946\end{array}$ & $\begin{array}{l}1.0 \\
1.3 \\
1.0 \\
1.5 \\
1.7\end{array}$ & $\begin{array}{r}0.9 \\
.9 \\
.9 \\
1.5 \\
1.3\end{array}$ & $\begin{array}{r}0.7 \\
.9 \\
.7 \\
1.1 \\
1.3\end{array}$ & $\begin{array}{r}0.5 \\
.7 \\
.8 \\
1.1 \\
1.2\end{array}$ & $\begin{array}{l}0.7 \\
1.2 \\
1.2 \\
1.6 \\
2.4\end{array}$ & $\begin{array}{l}\text { 1. } 1 \\
\text { 4. } 2 \\
\text { 3. } 8 \\
\text { 4. } 7 \\
\text { 8. } 0\end{array}$ & $\begin{array}{l}3.4 \\
13.0 \\
19.6 \\
11.2 \\
25.5\end{array}$ & $\begin{array}{r}6.9 \\
25.5 \\
47.8 \\
29.3 \\
65.2\end{array}$ & $\begin{array}{r}8.7 \\
34.6 \\
49.5 \\
\text { 33. } 9 \\
52.8\end{array}$ & $\begin{array}{r}6.8 \\
17.2 \\
25.5 \\
21.2 \\
34.1\end{array}$ & $\begin{array}{r}\text { 3. } 3 \\
8.0 \\
10.8 \\
9.8 \\
14.9\end{array}$ & $\begin{array}{l}2.2 \\
\text { 3. } 2 \\
\text { 4. } 0 \\
\text { 4. } 6 \\
6.2\end{array}$ & $\begin{array}{r}3.0 \\
9.3 \\
14.3 \\
10.3 \\
18.4\end{array}$ \\
\hline $\begin{array}{l}1947 \ldots \ldots \\
1948 \\
1949 \\
1950 \\
1951 \ldots \ldots\end{array}$ & $\begin{array}{l}2.4 \\
1.4 \\
\text { 3. } 9 \\
\text { 3. } 7 \\
\text { 5. } 3\end{array}$ & $\begin{array}{l}\text { 1. } 6 \\
\text { 1. } 0 \\
2.2 \\
\text { 3. } 4 \\
\text { 3. } 2\end{array}$ & $\begin{array}{l}\text { 1. } 2 \\
\text { 1. } 0 \\
2.0 \\
2.9 \\
1.8\end{array}$ & $\begin{array}{l}\text { 1. } 0 \\
\text { 1. } 1 \\
1.6 \\
2.1 \\
2.0\end{array}$ & $\begin{array}{l}\text { 1. } 3 \\
\text { 4. } 4 \\
\text { 3. } 3 \\
\text { 4. } 0 \\
\text { 3. } 0\end{array}$ & $\begin{array}{r}2.2 \\
9.2 \\
12.6 \\
9.1 \\
7.0\end{array}$ & $\begin{array}{r}5.6 \\
29.5 \\
41.8 \\
24.0 \\
22.8\end{array}$ & \begin{tabular}{|r}
16.1 \\
46.6 \\
115.0 \\
54.9 \\
59.5
\end{tabular} & $\begin{array}{l}30.4 \\
62.9 \\
81.3 \\
66.6 \\
54.9\end{array}$ & $\begin{array}{l}\text { 16. } 3 \\
36.6 \\
41.1 \\
49.7 \\
36.4\end{array}$ & $\begin{array}{r}8.0 \\
24.1 \\
23.7 \\
31.1 \\
16.7\end{array}$ & $\begin{array}{r}3.3 \\
11.5 \\
9.9 \\
11.4 \\
8.5\end{array}$ & $\begin{array}{r}7.5 \\
19.1 \\
28.4 \\
22.0 \\
18.6\end{array}$ \\
\hline $19521 \ldots \ldots$ & 5. 0 & 3. 0 & 2.1 & 2. 8 & 3. 7 & 11. 9 & 53. 0 & 96.0 & 121.7 & 94.0 & 29.5 & 16. 9 & 36. 9 \\
\hline
\end{tabular}

${ }^{1}$ Preliminary notifications. 
Figure 4. Poliomyelitis morbidity, seasonal incidence, United States, rafes by month, each year, $1942-52$.

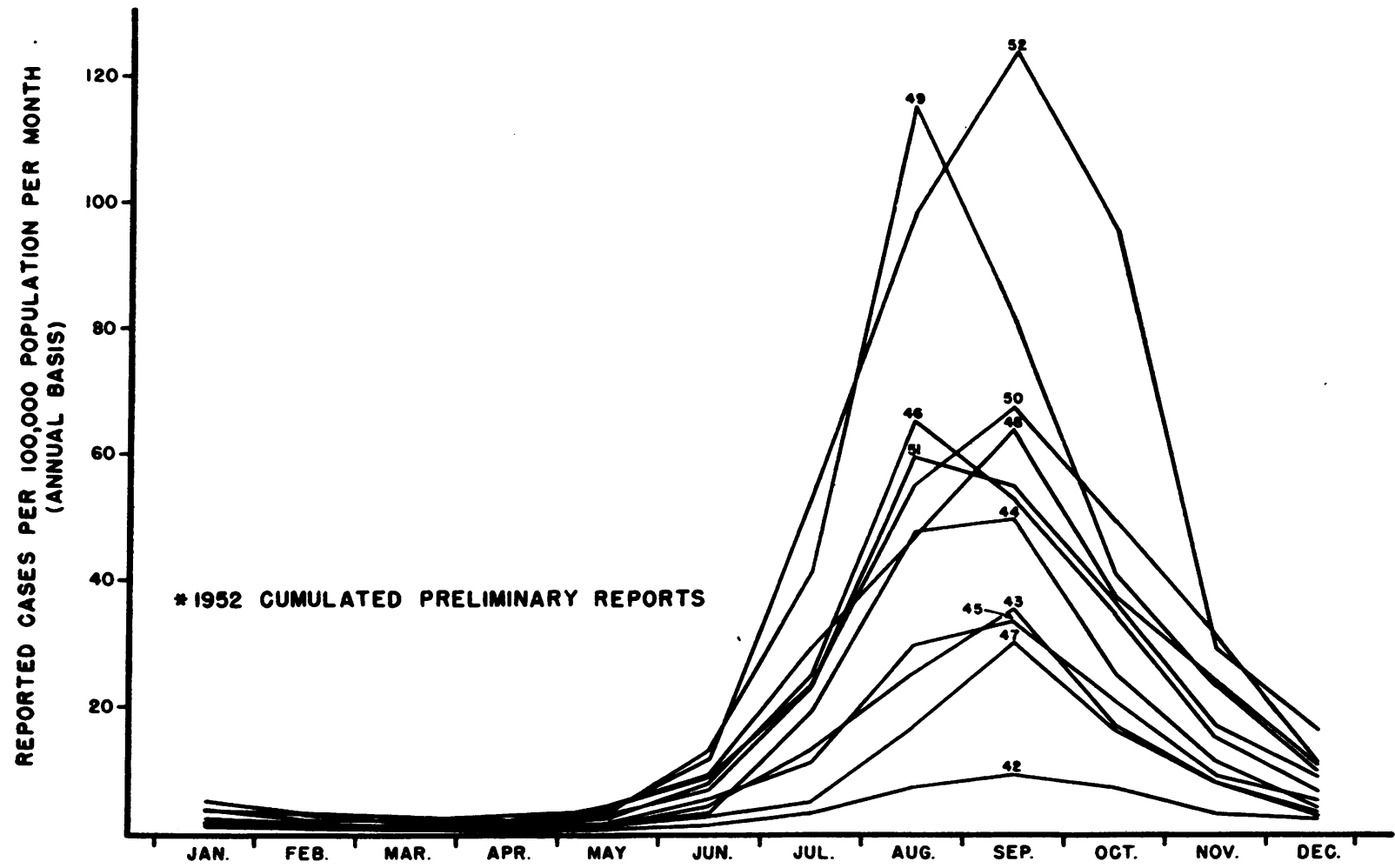

May, more rapidly in June and July, and reaches a maximum elevation in August and September. In October there is a marked decline which continues through succeeding months. In some years (fig. 4, table 7), August is the month of maximum incidence; in others, September; but in some, the attack rate has been approximately the same in both months, for example, the years 1944 and 1951. In two recent years, 1950 and 1952, the October rate has been relatively higher than in earlier years.

The seasonal change in incidence differs from one region of the United States to another (fig. 5, table 8) and these differences are re-

Table 8. Seasonal incidence of poliomyelitis in major geographic divisions, 10-year average, 1942-51

[Reported cases per month, per 100,000 population adjusted to annual base]

\begin{tabular}{|c|c|c|c|c|c|c|c|c|c|c|c|c|}
\hline Divisions & $\begin{array}{c}\text { Janu- } \\
\text { ary }\end{array}$ & $\begin{array}{c}\text { Febru- } \\
\text { ary }\end{array}$ & March & April & May & June & July & $\begin{array}{l}\text { Au- } \\
\text { gust }\end{array}$ & $\begin{array}{l}\text { Sep- } \\
\text { tem- } \\
\text { ber }\end{array}$ & $\underset{\text { tober }}{\text { Oc- }}$ & $\begin{array}{l}\text { No- } \\
\text { vem- } \\
\text { ber }\end{array}$ & $\begin{array}{l}\text { De- } \\
\text { cem- } \\
\text { ber }\end{array}$ \\
\hline $\begin{array}{l}\text { New England } \\
\text { Middle Atlantic } \\
\text { East North Central. }\end{array}$ & $\begin{array}{l}\text { 1. } 1 \\
\text { 1. } 4 \\
\text { 1. } 1\end{array}$ & $\begin{array}{r}0.5 \\
.9 \\
.8\end{array}$ & $\begin{array}{r}0.5 \\
.7 \\
.6\end{array}$ & $\begin{array}{r}0.4 \\
.7 \\
.5\end{array}$ & $\begin{array}{r}0.5 \\
.7 \\
.7\end{array}$ & $\begin{array}{l}1.7 \\
1.9 \\
2.3\end{array}$ & $\begin{array}{r}8.7 \\
11.2 \\
13.9\end{array}$ & $\begin{array}{l}\text { 41. } 6 \\
42.2 \\
52.8\end{array}$ & $\begin{array}{l}\text { 42. } 7 \\
\text { 48. } 2 \\
57.7\end{array}$ & $\begin{array}{l}24.2 \\
26.6 \\
33.8\end{array}$ & $\begin{array}{l}\text { 10. } 1 \\
11.6 \\
14.6\end{array}$ & $\begin{array}{l}\text { 3. } 8 \\
\text { 4. } 0 \\
\text { 5. } 5\end{array}$ \\
\hline $\begin{array}{l}\text { South Atlantic } \\
\text { East South Central } \\
\text { West South Central }\end{array}$ & $\begin{array}{l}\text { 1. } 8 \\
1.5 \\
\text { 3. } 5\end{array}$ & $\begin{array}{l}1.8 \\
1.8 \\
2.5\end{array}$ & $\begin{array}{l}1.2 \\
1.3 \\
2.9\end{array}$ & $\begin{array}{l}\text { 1. } 1 \\
1.3 \\
2.8\end{array}$ & $\begin{array}{l}2.4 \\
\text { 1. } 6 \\
\text { 8. } 4\end{array}$ & $\begin{array}{r}6.2 \\
6.2 \\
22.6\end{array}$ & $\begin{array}{l}\text { 20. } 0 \\
20.7 \\
37.2\end{array}$ & $\begin{array}{l}\text { 31. } 1 \\
\text { 30. } 0 \\
\text { 41. } 1\end{array}$ & $\begin{array}{l}27.5 \\
25.7 \\
30.4\end{array}$ & $\begin{array}{l}16.6 \\
15.8 \\
17.8\end{array}$ & $\begin{array}{r}9.2 \\
8.6 \\
12.3\end{array}$ & $\begin{array}{l}\text { 3. } 7 \\
\text { 3. } 8 \\
\text { 7. } 0\end{array}$ \\
\hline $\begin{array}{l}\text { West North Central } \\
\text { Mountain } \\
\text { Pacific }\end{array}$ & $\begin{array}{l}\text { 2. } 1 \\
\text { 5. } 1 \\
\text { 8. } 0\end{array}$ & $\begin{array}{l}\text { 1. } 5 \\
\text { 3. } 6 \\
\text { 4. } 7\end{array}$ & $\begin{array}{l}\text { 1. } 0 \\
\text { 3. } 3 \\
\text { 3. } 4\end{array}$ & $\begin{array}{l}\text { 1. } 1 \\
\text { 2. } 4 \\
\text { 2. } 7\end{array}$ & $\begin{array}{l}\text { 1. } 6 \\
\text { 3. } 9 \\
\text { 4. } 9\end{array}$ & $\begin{array}{r}4.4 \\
8.3 \\
11.2\end{array}$ & $\begin{array}{l}29.5 \\
25.6 \\
25.4\end{array}$ & $\begin{array}{l}\text { 77. } 9 \\
69.7 \\
48.0\end{array}$ & $\begin{array}{l}\text { 73. } 9 \\
69.3 \\
56.5\end{array}$ & $\begin{array}{l}44.6 \\
40.5 \\
42.8\end{array}$ & $\begin{array}{l}24.1 \\
22.2 \\
\text { 33. } 1\end{array}$ & $\begin{array}{r}8.7 \\
12.0 \\
17.9\end{array}$ \\
\hline United States_........ & 2.3 & 1. 7 & 1. 3 & 1.2 & 2. 3 & 6. 2 & 19. 6 & 46. 6 & 47. 3 & 28. 4 & 15. 1 & 6. 5 \\
\hline
\end{tabular}


Figure 5. Poliomyelitis morbidity, seasonal incidence, 10-year average rates by major geographic divisions, 1942-51.
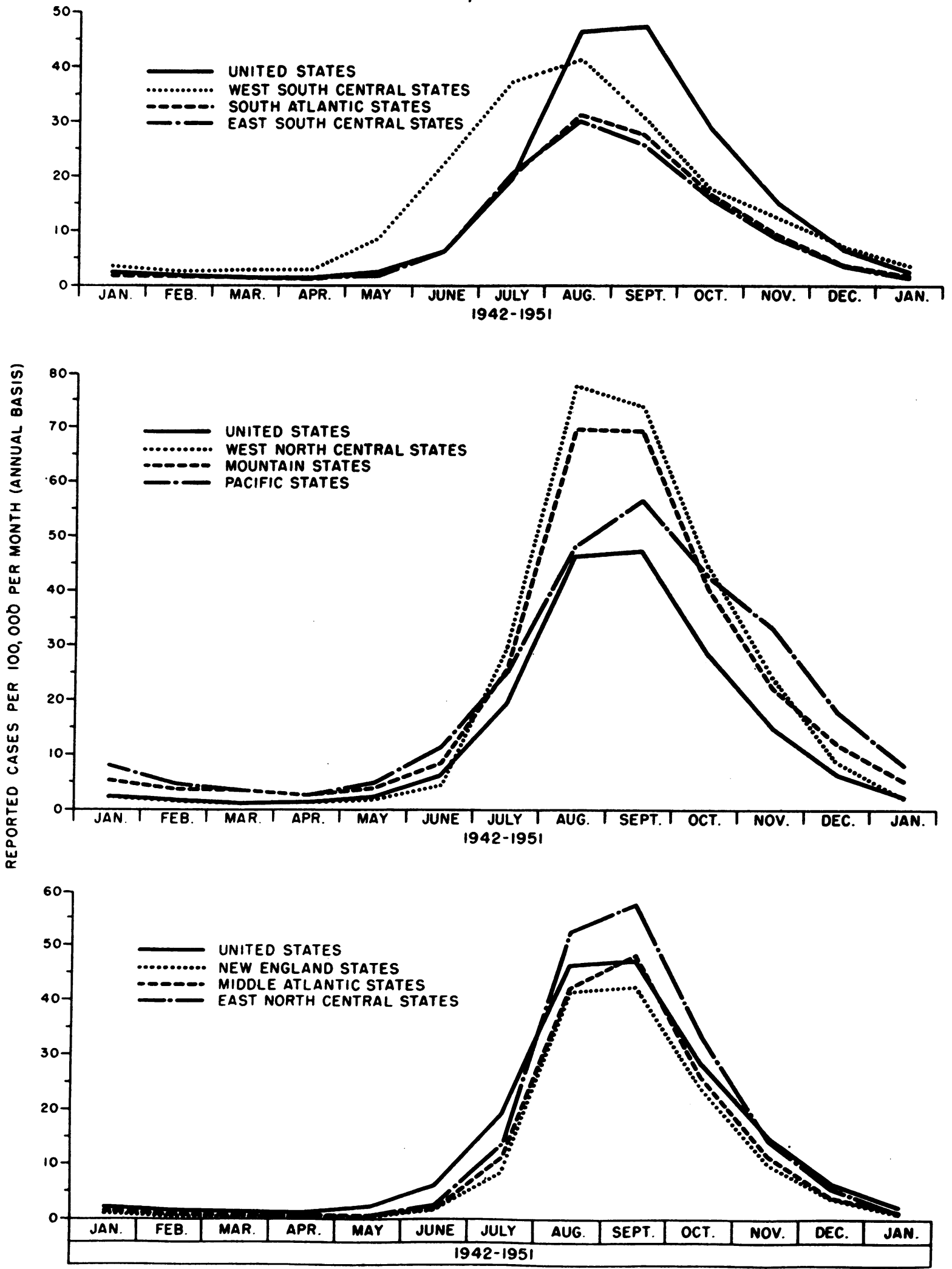
flected in the national curve of seasonal incidence as the center of epidemic intensity yearto-year moves from one area to another.

In the southern divisions of the United States, the initial rise occurs in May, reaching a maximum level in August; in the central and Pacific States, the rise begins in June and the high levels occur in August and September; and in the northeastern divisions the rise is not appreciable until July, and the highest average rates are observed in September. Generally, the epidemic span is shorter, with rise and fall more rapid, in northern latitudes.

Seasonal concentration of cases during a short epidemic period has been characteristic of the New England, Middle Atlantic, and East North Central States. In these divisions (table 9), 60 percent of the year's cases, on the average, have been reported during August and September. In the West North Central and Mountain divisions, concentration in these months has been similar but somewhat less pronounced. In these divisions, 50 to 55 percent of the total annual number of cases were reported during August and September in 1942-51.

In the South Atlantic, East South Central, and West South Central divisions, concentration in August and September has been less noticeable. Approximately 60 percent of the year's cases, on the average, were reported during July, August, and September. In the
Pacific.States, extension of the season of higher incidence into the fall months has been noticeable; 40 percent of the annual total cases, on the average, having been reported during August and September, and another 30 percent of the annual totals, during October and November.

\section{Summary}

Early descriptive accounts of poliomyelitis outbreaks in the United States have been reviewed and an analysis made of State morbidity reports since 1907 .

Poliomyelitis, a comparatively rare disease in the early years of this century, has since been recognized as a communicable disease problem in every State in the Nation. During the last 20 years the trend of the annual case rate has been upward, particularly during the last decade, during which a marked increase has occurred. The death rate has shown a slight but definite increase. In 1952, for the Nation, both the case rate and the estimated death rate were the highest since the 1916 epidemic. The ratio of reported deaths to reported cases has decreased over the last 20 years.

Earlier observers noticed that rates had been higher in the northern than in the southern regions of the country. In recent years this difference has diminished and an East-West differential is more prominent. In recent years both average and maximum rates have been

Table 9. Seasonal incidence of poliomyelitis in major geographic divisions; number of cases per month expressed as percentage of total cases, 10-year average, 1942-51

\begin{tabular}{|c|c|c|c|c|c|c|c|c|c|c|c|c|c|}
\hline Divisions & $\begin{array}{l}\text { Janu- } \\
\text { ary }\end{array}$ & $\begin{array}{c}\text { Febru- } \\
\text { ary }\end{array}$ & March & April & May & June & July & $\begin{array}{c}\text { Au- } \\
\text { gust }\end{array}$ & $\begin{array}{l}\text { Sep- } \\
\text { tem- } \\
\text { ber }\end{array}$ & $\begin{array}{c}\text { Octo- } \\
\text { ber }\end{array}$ & $\begin{array}{c}\text { No- } \\
\text { vem- } \\
\text { ber }\end{array}$ & $\begin{array}{c}\text { De- } \\
\text { cem- } \\
\text { ber }\end{array}$ & Total \\
\hline $\begin{array}{l}\text { New Eng } \\
\text { Middle A }\end{array}$ & $\begin{array}{r}0.8 \\
.9\end{array}$ & $\begin{array}{r}0.3 \\
.6\end{array}$ & $\begin{array}{r}0.4 \\
.4\end{array}$ & $\begin{array}{r}0.3 \\
.4\end{array}$ & $\begin{array}{r}0.4 \\
.5\end{array}$ & & & & & & & & \\
\hline $\mathrm{Ea}$ & .6 & .4 & .3 & .3 & .4 & 1.2 & 7. 6 & 29. 1 & 30. 7 & 18. 6 & & 3.0 & 100. \\
\hline ntic-..- & 1.4 & 14 & 10 & .9 & 2. 0 & 5. 0 & 16. 5 & 25. 7 & 21.9 & 13. 7 & 7.3 & 1 & 0 \\
\hline Cen- & 1.3 & 1.4 & 1.1 & 1.1 & 1.4 & 5. 1 & 17. 7 & 25. 7 & 21.3 & 13.5 & 7. 1 & 3. 3 & 100. \\
\hline$\ldots$ & 1.9 & 1. 2 & 1.5 & 1.5 & 4. 5 & 11.8 & 20. 0 & 22.1 & 15. 8 & 9.5 & 6.4 & 3. 8 & 100. \\
\hline $\begin{array}{l}\text { West North Cen- } \\
\text { tral } \\
\text { Mountain }\end{array}$ & $\begin{array}{r}.8 \\
1.9 \\
3.1\end{array}$ & $\begin{array}{l}.5 \\
1.2 \\
1.7\end{array}$ & $\begin{array}{l}.4 \\
1.3 \\
1.3\end{array}$ & $\begin{array}{r}.4 \\
.9 \\
1.0\end{array}$ & $\begin{array}{r}.6 \\
1.5 \\
1.9\end{array}$ & $\begin{array}{l}\text { 1. } 6 \\
\text { 3. } 1 \\
4.3\end{array}$ & $\begin{array}{r}11.1 \\
9.8 \\
10.0\end{array}$ & $\begin{array}{l}29.2 \\
26.6 \\
18.8\end{array}$ & $\begin{array}{l}26.8 \\
25.6 \\
21.5\end{array}$ & $\begin{array}{l}16.7 \\
15.4 \\
16.8\end{array}$ & $\begin{array}{r}8.7 \\
8.2 \\
12.6\end{array}$ & $\begin{array}{l}\text { 3. } 2 \\
\text { 4. } 6 \\
\text { 7. } 0\end{array}$ & $\begin{array}{l}100.0 \\
100.1 \\
100.0\end{array}$ \\
\hline United States.... & 1. 3 & .9 & .8 & .7 & 1. 3 & 3.4 & 11.1 & 26.4 & 26. 0 & 16. 1 & 8. 3 & 3. 7 & 100.0 \\
\hline
\end{tabular}


higher in the western and north central divisions of the United States than in the northeastern and southeastern divisions. Over extended periods of time geographic concentration has not been consistent.

In southern regions of the country, seasonal rise in incidence occurs earlier and the epidemic span is longer than in the northern regions.

\section{REFERENCES}

(1) Lavinder, C. H., Freeman, A. W., and Frost, W. H. : Epidemiologic studies of poliomyelitis in New York City and the Northeastern United States during the year 1916. Pub. Health Bull. No. 91, Washington, D. C., Government Printing Office, 1918.

(2) Aycock, W. L., and Eaton, P.: Seasonal prevalence of infantile paralysis. Seasonal variation in case fatality rate. Am. J. Hyg. 4: 681690 (1924).

(3) Aycock, W. L.: A study of the significance of geographic and seasonal variations in the incidence of poliomyelitis. J. Preventive Med. 3: 245-278 (1929).

(4) Wells, Mildred W.: Poliomyelitis. Baltimore, Md., Williams and Wilkins, 1932, pp. 306-478.

(5) Collins, S. D.: The incidence of poliomyelitis and its crippling effects, as recorded in family surveys. Pub. Health Rep. 61 : 327-355 (1946).

(6) Gilliam, A. G., Hemphill, F. M., and Gerende, J. H.: Average poliomyelitis incidence reported in counties of the United States, 19321946. Pub. Health Rep. 64 : 1575-1584 (1949).

(7) Gilliam, A. G., Hemphill, F. M., and Gerende, J. H.: Poliomyelitis epidemic recurrence in counties of the United States, 1932-1946. Pub. Health Rep. 64: 1584-1595 (1949).

(8) Sabin, A. B.: Poliomyelitis. Epidemiologic patterns of poliomyelitis in different parts of the world. Philadelphia, J. B. Lippincott Co., 1949, pp. 3-33.

(9) Hammon, W. McD., Coriell, L. L., and Stokes, J., Jr.: Evaluation of Red Cross gamma globulin as a prophylactic agent for poliomyelitis. 1. Plan of controlled field tests and results of 1951 pilot study in Utah. 2. Conduct of early follow-up of 1952 Texas and IowaNebraska studies. J. A. M. A. 150: 739-756 (1952).

(10) Hammon, W. McD., Coriell, L. L., Wehrle, P. F., Klimt, C. R., and Stokes, J., Jr.: Evaluation of Red Cross gamma globulin as a prophylactic agent for poliomyelitis. 3. Preliminary report of results based on clinical diagnosis. J. A. M. A. 150: 757-760 (1952).

(11) Caverly, C. S.: Notes of an epidemic of acute anterior poliomyelitis. J. A. M. A. 26: 1-5 (1896).

(12) Starr, M. A.: Epidemic infantile paralysis. J. A. M. A. 51 : 112-120 (1908).

(19) Holt, L. E., and Bartlett, F. H.: The epidemiology of acute poliomyelitis. Am. J. M. Sc., 135: 647-662 (1908).

(14) New York Neurologic Society, Collective Investigation Committee: Epidemic poliomyelitis report on the New York epidemic of 1907 . J. Nerv. \& Ment. Dis. Monograph series No. 6. 1910.

(15) McClanahan, H. M.: A brief report of the Nebraska epidemic of poliomyelitis. J. A. M. A. 55: 1160-1162 (1910).

(16) Dauer, C. C.: Studies on the epidemiology of poliomyelitis. Pub. Health Rep. : 53 : 1003-1020 (1938)； 54: 857-862 (1939)； 55: 955-961 $(1940) ; 56: 875-883 \quad(1941) ; 57: 710-716$ (1942); 58: 937-949 (1943); 59: 712-719 (1944); 60: 633-642 (1945); 61: 915-921 $(1946) ; 62: 901-909$ (1947)； 63: 393-396 (1948); 64: 733-740 (1949); 65: 782-787 $(1950) ; 66: 673-684 \quad(1951) ; 67: 524-526$ (1952).

\section{Type I Poliomyelitis Virus Adapted to Mice}

Successful adaptation of type I (Mahoney) poliomyelitis virus to Swiss mice has been achieved by Drs. C. P. Li and Morris Schaeffer of the Public Health Service Communicable Disease Center. Their report appears in the March 1953 issue of the Proceedings of the Society of Experimental Biology and Medicine, pages $477-481$.

The authors conclude that: "The use of the intraspinal route of inoculation and the selection of a mutant or variant of the virus is believed to be responsible for this adaptation. . . . With this attainment, all three poliomyelitis virus types have now been adapted to mice. This will permit for rapid progress in field and laboratory studies of poliomyelitis." The findings are important to poliomyelitis diagnosis and to the development of a live virus vaccine. 